\title{
Comprehensive analysis of former and new methods on conformity establishment of measuring instruments
}

\author{
Cherepkov Serhii', Dulia Valerii', Maliavskyi Valeriii ${ }^{3}$ Solomakhina Olena ${ }^{4}$ \\ 1,2,3,4 SE «Ukrmetrteststandart», Ukraine \\ E-mail: scherepkov@ukrcsm.kiev.ua
}

Abstract

\begin{abstract}
Taking into account five-year experience in measuring instruments conformity assessment with technical regulations requirements, gradual shift from the former system of testing and control to the new methods is considered according to the new Law of Ukraine «On metrology and metrological activity» ${ }^{[1]}$, which is harmonized with European Laws on metrology. Advantages of the system for measuring instruments conformity assessment with technical regulations requirements were determined and analyzed for instruments manufacturers and customers.
\end{abstract}

Keywords: measuring instruments, state testing, conformity assessment.

\section{Introduction}

State system of measuring instruments testing on conformity assessment with set requirements was existing for a long time in Ukraine. Active implementation of European principles and actions for providing a high level of the production safety required using new approaches, including mechanisms for its implementation. For that purpose, measuring instruments should be safe for single customer and protect unreliable measurement results affecting society. Conformity assessment of measuring instruments with set requirements became one of such mechanisms, corresponding to European principles and approaches. System of measuring instruments conformity assessment with set requirements was implemented in Ukraine from the 1-st of January 2016, the date of enforcement of the new redaction of the Law of Ukraine «On metrology and metrological activity» ${ }^{[1]}$. Taking into account, that term «conformity assessment» was frequently used in metrology sector before 2016, liquidation of state system of measuring instruments testing and implementation of the new system measuring instruments characteristics control naturally made domestic specialists in metrological activities, employees of enterprises and institutions, connected with production, supply and operation of the measuring instruments willing to compare these systems. System of measuring instruments conformity assessment was partially described in the articles «Assessment of the conformity of means of measuring equipment - realization in Ukraine of European approaches (principles)» ${ }^{[2]}$ and «Procedures for assessing the conformity of measuring instruments - structure, design principles and approaches to their choice» ${ }^{[3]}$, published in «Metrology and Instruments» journal. Nevertheless, 
manufacturers and users of measuring instruments still had plenty of questions concerning the functioning of the new system and its advantages to the state system of measuring instruments testing. All advantages and disadvantages of the implemented system of measuring instruments conformity assessment were impossible to define unambiguously compared to the former system at first. Still, after the last five years of system functioning, enough information and feedback from measuring instruments manufacturers were obtained in order to make a balanced comparative analysis of two systems.

\section{Main Body}

Authors are confident that the main principles of both systems functioning should be mentioned for making balanced comparative analysis of the state system of measuring instruments testing and system of measuring instruments conformity assessment.

Providing the unity of measurements in Ukraine, protection of citizens and state economy from unreliable measurement results is the main goal of both systems. This goal may be gained in case, if provided to customers measuring instruments conformity with set by regulatory documents requirements is established.

1. Ten years before changing the functioning of the state system of measuring instruments testing was regulated by the relevant at that time Law of Ukraine «On metrology and metrological activity» ${ }^{[1]}$ and national standard of Ukraine ${ }^{[4]}$. This standard was applicable to measuring instruments, which were assigned to serial production and were serially produced in Ukraine or were assigned to import and were imported in batches to Ukraine, except measuring instruments for use by persons, who are not subjects of business for their domestic purposes, which are not regulated by state metrological supervision.

Functioning of the system of measuring instruments conformity assessment is regulated by the relevant from the 1-st of January 2016 Law of Ukraine «On metrology and metrological activity» ${ }^{[1]}$, Law of Ukraine «On technical regulations and conformity as- sessment» ${ }^{[5]}$ and by corresponding technical regulations such as Technical Regulation on non-automatic weighing instruments ${ }^{[6]}$, Technical Regulation on measuring instruments ${ }^{[7]}$ and Technical Regulation on legal measuring instruments ${ }^{[8]}$. Force of these laws is applicable to legal measuring instruments, that is they should be used in the legal metrology sector, defined by Article 3 of the Law of Ukraine «On metrology and metrological activity». New system provides the possibility of conformity establishment with set requirements of measuring instruments serially produced in Ukraine or imported in batches as well as separate measuring instruments on the market. System of measuring instruments conformity assessment use provides equal conditions for measuring instruments producers and importers entering the market regardless of quantity indices on production or import of the measuring instruments. System provides clear information on the measuring instruments with obligatory conformity assessment for potential users.

2. State testing of the measuring instruments is divided into two parts: state acceptance testing and state control testing. State acceptance testing was provided for test samples of measuring instruments, which were assigned to serial production in Ukraine and for test samples of measuring instruments, which were serially produced by foreign manufacturers and were assigned to importing in batches. Proven state acceptance testing results were subject to type approval of measuring instruments and registering them in the State Register of Measuring Instruments (hereinafter - State Register). Measuring instruments of the approved types, which were serially produced by domestic manufacturers and measuring instruments of the approved types, which were serially produced by foreign manufacturers and imported in batches to Ukraine, were subject to regular state control testing, which was conducted every three years as a rule.

System of measuring instruments conformity assessment assumes using a particular conformity assessment procedure. Measuring instruments manufacturers use this procedure for demonstrating instruments conformity with the set requirements before their placing 
on the market. Conformity assessment procedures are set by technical regulations and are legally equal, but differ by methods and technique of their realization (involving the independent conformity assessment bodies, using methods of conformity assessment, etc.). Technical regulations envisage that measuring instruments manufacturers choose conformity assessment procedure. Let's emphasize that manufacturers can choose the procedure only from the list of conformity assessment procedures, which are set for particular legal measuring instruments category use by corresponding technical regulation. Taking into account certain risks for society, third party - designated conformity assessment bodies can be involved into conformity assessment of almost all legal measuring instruments.

Herewith, the new system is more flexible and provides an opportunity of choosing the most applicable conformity assessment procedure for measuring instruments manufacturer, based on certain economic and technical factors, such as financial condition of the enterprise, serial and regular production of measuring instruments or systematic products placement on the market, demand on certain measuring instruments categories, technical equipment condition, quality assurance system implementation, etc.

3. State bodies intervention into measuring instruments conformity establishment process should be emphasized.

State system of measuring instruments testing was totally regulated by the authorized central body of the executive power (CBEP) in metrology. Such body of executive power consequently was represented by State Committee of Ukraine on standardization, metrology and certification (Derzhstandart of Ukraine), The State Committee for Technical Regulation and Consumer Policy (Derzhspozhyvstandart, of Ukraine) and the Ministry of Economy of Ukraine.

According to National Standard of Ukraine ${ }^{[4]}$ CBEP performs the following functions:

- authorizing metrological centers and local bodies on state acceptance and state control testing of the measuring instruments;
- organizing and conduct of state acceptance testing of measuring instruments and state control testing of measuring instruments imported in batches to Ukraine;

- analyzing results of state testing of measuring instruments;

- approving measuring instruments types and registering procedure;

- issuing certificates on type approval of measuring instruments, certificates on conformity of measuring instruments with the approved type and certificates on recognition of type approval of measuring instruments based on international agreements of Ukraine;

- deleting measuring instruments types from the State Register, if such measuring instruments do not conform with the approved type and (or) regulatory documents requirements;

- organizing official information issue about registered types of measuring instruments.

Therefore, activities on conformity establishment of measuring instruments with regulatory documents requirements, starting from planning, organization and conduct of state testing of measuring instruments up to analyzing their results and issuing certificates needed state body intervention, which was recognized by measuring instruments manufacturers as very burdensome, even excessive in some cases.

State regulation by the new state system is significantly reduced to such elements as:

- approval of legal measuring instruments types, which require conformity assessment;

- establishment of requirements to legal measuring instruments and conformity assessment procedures development, taking into account particular risks for society;

- designation of bodies on measuring instruments conformity assessment.

At the same time, conformity assessment system increased the responsibility level of designated bodies on conformity assessment for established 
activities with the necessary diligence and technical competence, causing conditions for impartiality of such bodies.

Authors are confident that such level of state influence is sufficient for ensuring use of legal measuring instruments, which conform with the Law of Ukraine «On metrology and metrological activity» ${ }^{[1]}$ and other regulatory documents, which include requirements to such measuring instruments.

4. According to the authors point of view, special attention should be paid to the issue of results accounting for establishment of measuring instruments conformity with set requirements and issuing certificates.

According to DSTU ${ }^{[4]}$ proven results of state acceptance testing of measuring instruments were the basis for measuring instruments type establishment and entering the State Register ${ }^{[4]}$. The Registration procedure was regulated by Order «On State Register of measuring instruments» ${ }^{[9]}$, which was approved by corresponding Decree of CBEP (in the last edition of Order it was Decree of Derzhspozhyvstandart of Ukraine). Official information concerning registered measuring instruments was published in annual Registers. Registers included name and notation conventions of measuring instrument, number in State Register and manufacturers name.

Serial production of measuring instruments in Ukraine or their import in batches to Ukraine was possible after measuring instrument type approval and registration.

Registered measuring instruments and their manuals should be identified by Mark of measuring instruments type approval. Format and size of the Mark were approved by DSTU ${ }^{[4]}$.

After registration of the approved types of measuring instruments in the State Register CBEP issued type approval certificates. Such certificate could be issued to:

- developer of measuring instruments assigned to serial production in Ukraine and enterprise planning their production;
- foreign manufacturer of measuring instruments assigned to import in batches to Ukraine or official importer in Ukraine.

CBEP issued certificates on conformity of measuring instruments with approved types for manufacturers of measuring instruments based on proven results of:

- $\quad$ state control testing provided in the first year of measuring instruments of approved types serial production;

- first state control testing of measuring instruments imported in batches to Ukraine;

- $\quad$ repeated state control testing of measuring instruments.

Certificate on conformity of measuring instruments with approved types, which were serially produced in Ukraine was also the document approving conformity of those instruments with set requirements of the regulatory documents, including safety requirements ${ }^{[4]}$.

Type approval and certificates issue conditions have significantly changed after the system of measuring instruments conformity assessment implementation. New redaction of the Law of Ukraine «On metrology and metrological activity» ${ }^{[1]}$ and corresponding technical regulations define that designated conformity assessment bodies issue certificate of type evaluation of measuring instruments (hereinafter evaluation certificate) based on proven results of research and testing, conducted according to the part of conformity assessment procedure, particularly module B (type evaluation). Evaluation certificate confirms that type of measuring instrument is approved. Evaluation certificate is valid for 10 years unlike the former certificate on type approval of measuring instruments, which had no expiration date.

State Register maintaining was suspended on the 1-st of January 2016. Creation of the Register of approved types of measuring instruments started instead. Order of the Ministry of Economic Development and Trade of Ukraine dated 13.07.2016 № $1161^{[10]}$ 
defined order of maintaining this Register. Register of approved types of measuring instruments is online database and is formed based on information from designated bodies about issued by them certificates on type evaluation. State Enterprise «All-Ukrainian state research and production center for standardization, metrology, certification and consumers' rights protection» (SE «Ukrmetrteststandart») is authorized on maintaining and publishing Register of approved types of measuring instruments on the own web-site. Thus, information from the Register of approved types of measuring instruments is public.

Approved types of measuring instruments placement in the Register, unlike State Register, are not subject to serial production of the measuring instruments in Ukraine or their import in batches to Ukraine. Manufacturer can produce or import to Ukraine measuring instruments of the approved type, but he cannot place them on the market. Due to the fact that issuing a certificate of type evaluation by designated conformity assessment bodies confirms that the manufacturer performed only part of the conformity assessment procedure for measuring instruments.

According to the closing part of conformity assessment procedure used by manufacturer possibility to place measuring instrument on the market can be either conformity certificate or valid decision of conformity assessment body, that quality management system of manufacturer ensures conformity of produced measuring instruments with defined in the certificate type and particular requirements of Technical Regulations.

Designated conformity assessment body issues conformity certificates based on proven results of research and testing, provided with measuring instruments before placing them on the market. Conformity certificate has no expiration date unlike certificates on conformity of measuring instruments with the approved type, which was valid for 3 years from date of act on state control testing approval. Since conformity certificate is issued for a particular sample or batch of measuring instruments specifying their name, notation conventions and serial number. Manufacturer should keep certificates for 10 years from the date of measuring instruments introduction into circulation for submitting them to bodies of market supervision.

Conformity assessment body informs measuring instruments manufacturers concerning the decision on produced measuring instruments conformity with type in the certificate of type evaluation, particular requirements of Technical Regulations and quality management system approval. Decisions may be issued as certificates of quality management system approval.

Moreover, manufacturers can use conformity assessment procedures without measuring instruments type evaluation. Mostly such a procedure is used for the particular batch or for one particular measuring instrument. Conformity certificate is issued for such measuring instruments after receiving the proven results.

For measuring instruments specified in conformity certificate or for measuring instruments manufactured during proven results validity term concerning quality of production process, manufacturer issues declaration of conformity. Each measuring instrument, for which conformity certificate was received, is supplied with the copy of declaration.

After measuring instruments passed conformity assessment, manufacturers should put the conformity mark and additional metrological marking on them due to corresponding technical regulation. Additional metrological marking should include two last digits of its application year. Designated body should also mark the measuring instrument with its identification number. Thus, information on particular technical regulation conformity, year of conformity assessment and particular body providing this assessment unlike Sign of measuring instrument type approval, which marked only the fact of measuring instrument type entering the State Register.

\section{Conclusions}

Taking into account this brief comparative analysis, authors conclude that system for measuring instruments conformity assessment unlike state system of measuring instruments testing: 
- $\quad$ is not orientated only on serially produced in Ukraine or imported in batches measuring instruments, and is orientated on each legal measuring instrument;

- decreases state bodies regulatory influence and increases responsibility of designated conformity assessment bodies for results of their activities;

- $\quad$ is more flexible and variable in conformity assessment procedures choice for manufacturer and designated conformity assessment body and at the same time requires more responsibility from manufacturer for final result, which is market placement of the meeting requirements measuring instruments;
- is more clear and informative concerning accounting and processing results of measuring instruments conformity assessment.

Notwithstanding that implementation experience demonstrates that the system for measuring instruments conformity assessment needs particular improvement, one can conclude that this system is more applicable for health protection and care, environmental and natural resources protection, energy efficiency support, property protection, national safety ensuring and protection, and misleading business activity prevention.

\section{References}

1. Law of Ukraine «On metrology and metrological activity» from 05.06.2014, № 1314 - VII [Закон України «Про метрологію та метрологічну діяльність» від 05.06.2014, № 1314 - VII]. [In Ukrainian]

2. Kuzmenko Y., Cherepkov S., Dulya V. 2018 Assessment of the conformity of means of measuring equipment - realization in Ukraine of European approaches (principles) [Оцінка відповідності засобів вимірювальної техніки - реалізація в Україні європейських підходів (принципів)]. Metrology and Instruments. 1 (69), pp. 11 - 16. [In Ukrainian]

3. Cherepkov S., Dulya V., Maliavskyi V. 2019 Procedures for assessing the conformity of measuring instruments structure, design principles and approaches to their choice [Процедури оцінки відповідності засобів вимірювальної техніки - структура, принципи розроблення та підходи до їх вибору]. Metrology and Instruments. 1 (75), pp. 56 - 61. [In Ukrainian]

4. DSTU 3400:2006 Metrology. State testing of measuring instruments. Basic principles, organization, procedure, and consideration of results [ДСТУ 3400:2006 Метрологія. Державні випробування засобів вимірювальної техніки. Основні положення, організація, порядок проведення та розгляду результатів]. [In Ukrainian]

5. The Law of Ukraine «On technical regulations and conformity assessment» from 15.01.2015, № 124 - VIII [Закон України «Про технічні регламенти та оцінку відповідності» від 15.01.2015, № 124 - VIII]. [In Ukrainian]
6. Technical Regulation on non-automatic weighing instruments, approved by the Cabinet of Ministers of Ukraine Act from 16.12.2015, № 1062 [Технічний регламент щодо неавтоматичних зважувальних приладів, затверджений Постановою Кабінету Міністрів України від 16.12.2015, № 1062]. [In Ukrainian] 7. Technical Regulation on measuring instruments, approved by the Cabinet of Ministers of Ukraine Act from 24.02.2016, № 163 [Технічний регламент засобів вимірювальної техніки, затверджений Постановою Кабінету Міністрів України від 24.02.2016, № 163]. [In Ukrainian]

8. Technical Regulation on legal measuring instruments, approved by the Cabinet of Ministers of Ukraine Act from 13.01.2016, № 94 [Технічний регламент законодавчо регульованих засобів вимірювальної техніки, затверджений Постановою Кабінету Міністрів України від 13.01.2016, № 94]. [In Ukrainian]

9. Order on State Register of measuring instruments, approved by the Order of Derzhspozhyvstandart of Ukraine from 22.08.2005, № 218 [Положення про Державний реєстр засобів вимірювальної техніки, затверджене Наказом Держспоживстандарту України від 22.08.2005, № 218]. [In Ukrainian]

10. Order on approving the Procedure of maintaining the State Register of approved types of measuring instruments, approved by the Order of the Ministry of Economic Development and Trade of Ukraine dated 13.07.2016, № 1161 [Порядок ведення Реєстру затверджених типів засобів вимірювальної техніки, затверджений Наказом Міністерства економічного розвитку і торгівлі України від 13.07.2016, № 1161]. [In Ukrainian] 